\title{
The Implementation of Grammatical Error Analysis to Improve Students' Writing Skill on Recount Text for Students Class X MIA At SMA Tri Dharma Kosgoro Dompu
}

\author{
Nadiya Arnillah \\ SMA Tri Dharma Kosgoro, Dompu, Nusa Tenggara Barat \\ E-mail: nadiyaarnillah@gmail.com
}

\begin{tabular}{l}
\hline Article Info \\
\hline Article History \\
Received: $2021-11-02$ \\
Revised: $2021-11-22$ \\
Published: $2021-12-04$
\end{tabular}

Keywords: Recount Text; Action Research; Error Analysis; Writing.

\begin{abstract}
This study is a classroom action research that focuses on the implementation of grammatical error analysis to improve students' writing skill on recount text for students. The study conducted at SMA Tri Dharma Kosgoro Class X MIA that consisted of 25 students; 15 male and 10 female. Apart from implementing the grammar error analysis to enhance students' writing skill, the researcher also identify some errors of students' writing particularly on grammatical error and analyze some factors of these errors. The implementation of this research was in cycle I that consist of eight meetings. Study shows that the implementation of grammatical error analysis can enhance the students' understanding in writing recount text. This has been shown by the improvement of student's score. Moreover, the kinds of the students' grammatical errors could be classified into seven categories namely errors in verb groups, errors in subject and verb agreement, errors in article, errors in pluralization, errors in conjunction, errors in preposition, and errors in pronoun. The identification of these type of grammatical error is paramount due to these could help students understand some components of grammar that students should master to improve their understanding in writing recount text.
\end{abstract}

\begin{tabular}{l}
\hline Artikel Info \\
\hline Sejarah Artikel \\
Diterima: 2021-11-02 \\
Direvisi: 2021-11-22 \\
Dipublikasi: $2021-12-04$
\end{tabular}

Kata kunci: Teks Pengalaman; Penelitian Tindakan; Analisis Kesalahan; Menulis.

\begin{abstract}
Abstrak
Penelitian ini merupakan penelitian tindakan kelas yang berfokus pada penerapan analisis kesalahan tata bahasa untuk meningkatkan keterampilan menulis siswa pada teks recount bagi siswa. Penelitian dilakukan di SMA Tri Dharma Kosgoro Kelas X MIA yang terdiri dari 25 siswa; 15 laki-laki dan 10 perempuan. Selain menerapkan analisis kesalahan tata bahasa untuk meningkatkan keterampilan menulis siswa, peneliti juga mengidentifikasi beberapa kesalahan penulisan siswa terutama pada kesalahan tata bahasa dan menganalisis beberapa faktor kesalahan tersebut. Pelaksanaan penelitian ini pada siklus I yang terdiri dari delapan pertemuan. Studi menunjukkan bahwa penerapan analisis kesalahan tata bahasa dapat meningkatkan pemahaman siswa dalam menulis teks recount. Hal ini ditunjukkan dengan peningkatan nilai siswa. Selain itu, jenis kesalahan tata bahasa siswa dapat diklasifikasikan ke dalam tujuh kategori yaitu kesalahan dalam kelompok kata kerja, kesalahan dalam subjek dan kesepakatan kata kerja, kesalahan dalam artikel, kesalahan dalam pluralisasi, kesalahan dalam konjungsi, kesalahan dalam preposisi, dan kesalahan dalam kata ganti. Identifikasi jenis kesalahan tata bahasa ini sangat penting karena ini dapat membantu siswa memahami beberapa komponen tata bahasa yang harus dikuasai siswa untuk meningkatkan pemahaman mereka dalam menulis teks recount.
\end{abstract}

\section{INTRODUCTION}

English is an international language. It is spoken by many people in the world, either as a first or a second language. English is also very important in education. Students' are expected to able to comprehend English language including its language skills. Language skills cover four primary skills. They were listening, writing, speaking, and reading, In Indonesian education system, English is taught from elementary school. However, many students claim that English is very difficult to learn. They learn English because they have to, not because they are interested to learn it. Because of that, for some of them, English is seemed to be very difficult. From the four skills (Listening, writing, speaking, and reading) writing skill seems to be the most difficult than the other skills, Writing is one of the four basic skills. Writing involves some language components (spelling, vocabulary, grammar and punctuation). This is in line with what is stated by Sakkir (2020) writing skill consists of many aspects of language that should be covered. Further, Sakkir (2020) argues that writing is complex and sometimes difficult to teach because requiring mastery not only of grammatical and 
theoretical devices but also of conceptual and a judgment element that's why teaching writing is different from other aspects of language skills. Braine and May (1996 in Budiman 2010:1) also state that writing clear sentence requires students to learn the rules of English grammar and mechanics such as the correct use of verbs and pronouns, as well as commas and other marks of punctuation. In writing, students often get confused about the thing they should do first and the grammar they have to use. Although they have done this activity maximally, however, they still make error in writing. Another problem that had found by the researcher that the students found it difficult to understand components of grammar in recount text. Therefore, it affected their score result in writing skill.

Based on the writer experience in teaching students class X MIA at SMA Tri Dharma Kosgoro, many students found it difficult to write recount text and made errors when their writing recounts text especially in terms of grammatical feature. The study of errors is important for a learning process. It means that by studying the errors we can identify some types of errors and their reason to occur. The reasons may deal with the students' knowledge of English which affected their ability in writing. Similarly, grammar also plays as an important element to make a well structured writing and student's speaking (Purwati, 2020).

As has been stated on the problem, this study focuses on the implementation of grammar analysis to improve students' skill in writing recount text. It has been known that recount text is one type of texts learned in high school level, especially for the first year students.. Furthermore, this study tried to find out the possible reasons that may cause those errors to occur. This may provide valuable inputs in finding out some solutions to help both students and teachers to have better quality of English learning especially in writing recount text.

1. Research Questions

Based on the background of the study above the researcher found the answers to the following question:

a) What kind of grammatical errors made by the students class X MIA at SMA Tri Dharma Kosgoro in writing recount text?

b) How can the implementation of grammatical error analysis improve the students understanding in writing recount text?

2. Review of Related Literature

Writing seems to have taken on different definitions for different groups of people in order to suit their different needs and purposes for writing. Even for professionals involved in the field of English Language Teaching, not one definition of writing could satisfy everyone, For the process oriented professionals and researchers, writing is a product of a person's search for meaning. Zamel (1982) points out that writers go through the process where meaning is created because writers seem to start off the process not knowing what they are going to say at all.

Grabe and Kaplan (1996), in their book "Theory and Practice of Writing", explore the meaning of writing in terms of the rhetorical triangle in writing. And such triangle consists of the reader, the recipient of the final product of the writing process; the writer, the originator of the message; and the subject matter and text itself. Both the writer and the reader have to consider all these aspects when writing and reading, respectively, for each one plays a significant role in the journey towards meaning, according to Klein (1985), writing is the ability to put pen and paper to express ideas through symbols. This way, representations on the paper will have meaning and content that could be communicated to other people by the writer.

a) Grammatical in Language Learning Grammar is the system of a language. People sometimes describe grammar as the "rules" of a language; but in fact no language has rules. If we use the word "rules", we suggest that somebody created the rules first and then spoke the language, like a new game. But languages did not start like that. Languages are started by people making sounds which evolved into words, phrases and sentences. No commonly-spoken language is fixed. All languages change over time. What we call "grammar" is simply a reflection of a language at a particular time. Do we need to study grammar to learn a language? The short answer is "no". Many people in the world speak their own, native language without having studied its grammar. Children start to speak before they even know the word "grammar". But if you are serious about learning a foreign language, the long answer is "yes, grammar can help you to learn a language more quickly and more efficiently." It's important to think of grammar as something that can help you, like a friend. When you understand the 
grammar (or system) of a language, you can understand many things yourself, without having to ask a teacher or look in a book.

Grammar can be defined as a set of shared assumptions about how language works (Yulianti, 2007 in Hartanti, 2009). The assessment whether the learners have mastered some grammatical points should not be based on their ability to state the rules of grammar, but on their ability to use the grammatical points to share their ideas, emotions, feelings, or observations with other people. Especially in the context of the teaching English in Indonesia, the teaching of grammar should be integrated in the development of the four language skills.

b) The Definition of Error

In terms of etymology, the words are more deeply differentiated. The word 'error' came from the Latin word 'errorem' or 'errare', which means 'to wander or stray'. The root of the word 'mistake', nails the meaning more correctly. It is from the Old Norse word, 'mistaka', which means 'mis' (wrong) and 'taka' (take). As a whole, it means 'wrongly taken'.

Errors are indispensable to learners since the making of errors can be regarded as "a device the learner uses in order to learn" (Selinker in Ningsih 2008:7). The errors themselves are competence errors. According to Corder, true errors are marker of the learner's competence (Richards, 1974).

An error is different from mistake or slip, so we have to be careful to differentiate. Error is caused by the factor of competence; it means that the students have not mastered the linguistic system yet. The error is characteristically being systematic. The correction is usually done by the teacher, for example by teaching remedial and exercises. Some people said that errors are the illustration of the students' comprehension of the language system that they are learning. In this case, we can say that the error refers to the failure to use the system correctly caused by the lack of the learner's competence.

A mistake refers to a performance error that is either random or a slip of tongue, in that it is failure to utilize a known system correctly (Brown, 1980:165 in Haryanto, 2007:16). Mistake is caused by the factor of performance and the limitedness to remind something. Mistake is also characteristically be unsystematic, the correction can be done by the students itself if they have more concentration, because the students have mastered the linguistic system of the language but because of something he/she forgot about those system, this forgetness usually temporary. Further, we can say that mistake is nothing to be worried; a mistake is just a slip that the learner forgets the right form, but errors must be treated seriously because the learners does not know the rule and they will make it repetitively.

c) Recount Text

Definition of recount is a text which tells the reader a past even and it usually focuses on person's past experience. The social purpose of recount text is not only to inform the readers but also to entertain the reader, The generic structures of recount text are:

a) Orientation/setting: the background of the story. It answers the questions: Who? When? Where? What experience?

b) List of events: this presents the sequence events that happened. Usually it presents the event chronologically.

c) Reorientation: this presents the concluding comments and personal opinion of writer toward the events.

A recount has a little, which summarizes the text. Since recount tells about past experience, it uses past tense; such as simple past, past perfect, past continuous, past perfect continuous tenses. (Hariyanto, 2007:13 in Nazri: 2010), A recount describes events, so plenty of use is made of verbs (action words), and of adverbs (describes or add more detail to verbs). And since it describes events in a chronological order, to describe the events words which link events in time can be used, such as next, later, when, then, after, before, first. (Hariyanto, 2007:14 in Nazri: 2010)

Many other researchers conducted studies in line with this research, such as one by Tony Hariyanto (in Nazri 2010:15) who conducted the study entitled "Grammatical Error Analysis in Students' Recount Texts". The participants of his study were the immersion class of 
twelfth grade students of SMAN 1 Slawi, Tegal in the academic year of 2006/2007 which consists of two classes; they were XII IA5 and XII IA6. Each of them consists of 19 students. Thus, the total number of the participants is 38 students. And Haryanto chose ten of them randomly with a reason because those students have already learnt the English grammar and they also used more English in the classroom teaching-learning process then the non-immersion class students. So in conducting his research Hariyanto come to the field, explained what recount is, to refresh the students' understanding about recount itself, got them writing a recount, analyzed and described the errors made by the students. $\mathrm{He}$ found that there were 235 grammatical errors with various kinds done by students. To make it easier Hariyanto classified those errors into 7 parts of errors, errors in using verb groups, errors in the use of articles, use of preposition, errors in pluralization, use of pronouns and errors in the use of conjuctions.

Ayu Istiqomah (2009) also conducted the study entitled Common Grammatical Error in Writing Recount Text. The objective of her thesis is describing the grammatical errors in writing made by the first year students of SMA N 3 Tegal in the academic year of 2009/2010. Only 30 students were taken in random as the sample. She uses the qualitative approach of which the data are obtained from the students' recount text writing. She analyzed and classified into nine groups. They are errors in using noun, errors in using pronoun, errors in using verb, errors arising from the confusion of adjectives and adverbs, errors in using preposition, errors in using article, errors in using conjunction, errors in using punctuation and errors in word order. Ayu concluded that the students made 273 grammatical errors that consist of 151 errors in using verb, 30 errors in using pronoun, 26 errors in using noun, 20 errors in using punctuation, 20 errors in using preposition, 18 errors in using article and 7 errors in word order.

\section{RESULTS AND DISCUSSION}

In this study, the researcher used classroom action research method because the researcher want to improve the students' skill in writing recount text by implementing grammatical errors analysis in writing recount text of X MIA class at SMA Tri Dharma Kosgoro. Ebbutt (1985) in Hopkins (1993: 45) states that action research is about the systematic study of attempts to improve educational practice by groups of participants and by means of their own practical actions and by means of own reflection upon the effects of those actions. The cycle of action research is described as follows:

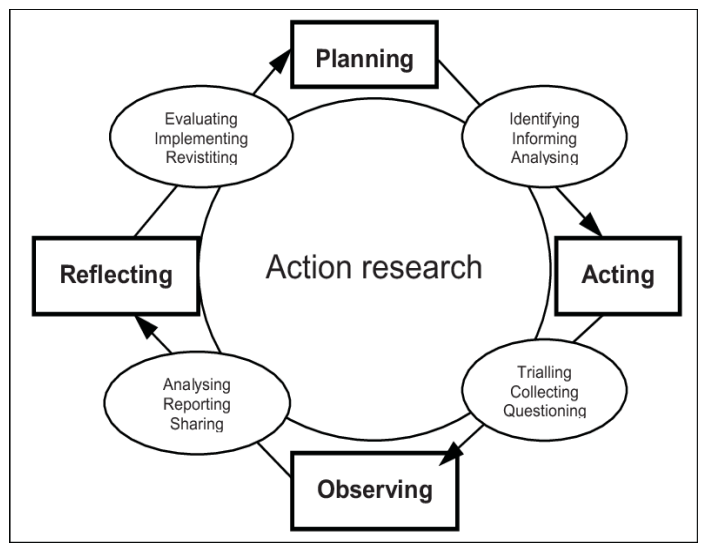

The model of action research in this classroom action research is developed by Lewin in Penelitian Tindakan (Action Research) written by Tim (2000: 11) cited in Dyan (2010). Based on the model, there are four steps in implementing the action research: (1) planning; (2) acting; (3) observing; and (4) reflecting.

1. Instrument of Collecting Data

In this research to collect the data, the researcher used two instruments to support the data analysis. They were writing test and questionnaire, In writing test, the researcher did pre-test and post-test in order to check the students' writing score before and after treatment. First, the researcher used the writing test as the research instrument. The test is intended to find out the grammatical errors that the students' made. Before giving the test, the researcher explained what recount text is to refresh the students' understanding and memory about recount text itself, second, in order to get additional information the researcher gave the students some questions in the form of questionnaire to obtain information dealing with the possible factors that cause the errors they made.

2. Method of Data Analysis

This investigation used descriptive method. The data collected from the result of the students' tests. To analyze the data, the researcher used quantitative and qualitative procedure. Quantitative procedure is conducted by percentaging the errors made by the students. While the qualitative procedure 
is needed to describe the causes of the students errors in writing recount text.

3. Explanation of Students' Errors (acting/ treatment)

In this point, the researcher explained and elaborated the seventh errors based on the classification of the students' errors in writing recount text and gave some examples of each classification. Afterwards, the researcher analyzed the obtained data in calculating the frequency of individual student's errors in their writing recount. The researcher computed the data with following formula:

$$
\begin{aligned}
& \mathbf{P}=\frac{n 1}{\Sigma N} \times 100 \% \\
& \text { In which: } \\
& \mathrm{P}=\text { Percentage of errors } \\
& n 1=\text { Number of errors made by students } \\
& \Sigma N=\text { Number of students }
\end{aligned}
$$

\section{RESULTS AND DISCUSSION}

All of these findings had been implemented into one cycle that consisted of eight meetings. This eight meetings consisted of implementing the research and testing the students that had been implemented two months, The researcher conducted the pre-test and post-test for checking the students' understanding after the implementation of grammatical error analysis. The researcher made a preparation to conduct the research by preparing the lesson plan, identify the problem, and preparing the worksheet for students. Moreover, the researcher also selected the appropriate teaching method for teaching and identifying the students' grammar error. The following is the presentage of students' score in both pre-test and post-test:

\begin{tabular}{ll}
\hline Pre-test & Post-Test \\
\hline $45.7 \%$ & $51.7 \%$ \\
\hline
\end{tabular}

In short, based on the presentage above, it can be concluded that there is an improvement of students' score before and after the implementation of the error analysis strategy. Although the percentage is not high significantly, this precentage can represent the differences the students' understanding in recount text before and after the treatment.

\section{A. Identification of Students' Errors}

After collecting and analyzing the students' writings, the researcher found there were many grammatical errors in writing recount made by the students.
Based on the analysis, there were one hundred and eighty seven (187) grammatical errors that students made in their writing recount. They were 97 errors in verb group, 21 errors in subject-verb group, 16 errors in article, 6 errors in pluralization, 7 errors in conjunction, 30 errors in preposition and 11 errors in pronoun, some of the sentence errors produced by the students are the following:

1. We taken picture together

2. One year ago, I and my friend to go Senggigi beach

3. I and my big family gone to Gili Terawangan

4. After that, I try some games in Jawa Timur Park

5. We amazed with the view in Benang Kelambu

6. My father parking my car

7. That is my bad experience

8. I am happy go to Kerandangan

9. That is my story in holiday

10. We were together ordering bus to went there

11. That time I go to played with my friend

12. I have good experience

13. I do not know who have the earring

14. I will never forget that experience

15. We can saw the panorama beautiful in Senggigi beach

16. When we go to Senggigi beach the panorama is beautiful

17. I went there with 4 my best friend, they are agus, gunawan, made and komang

18. In the way my mother and I get a accident

19. I was very happy together all my friend

20. Two week ago I and my friends went to Mangsit beach by bicycle

21. Last year I went to Senggigi beach together my family

22. We continued journey to Gili terawangan

23. Afternoon, I with my friend go to canteen

24. I went to Jawa Timur Park with car

In order to have clear identification about the errors, the researcher classifies the errors as follows.

\section{B. Classification and Explanation of Students' Errors}

In this step, the researcher classifies and explains the errors made by the students into errors in verb group, errors in subject-verb agreement, errors in article, errors in pluralization, errors in conjunction, errors in 
pronoun, and errors in preposition. (Hariyanto, 2007)

1. Errors in verb groups

Based on the results found, the students made the most errors in verb groups. Errors in verb groups consist of errors in using past tense, linking verb (to be), modal, auxiliary verb and infinitive that students made in writing recount.

a) Past Tense

Many students made errors in simple past tenses. They mainly used the simple present in their writing instead of the simple past tense. As we know the past tense is to talk about activities or situations that began and ended in the past. In English, there are two main types of verb namely Regulars and Irregulars verb. Most simple past are formed by adding -ed to the verbs except for some irregular verbs. In line with this, the students made errors in using regular and irregular verbs. Some of the errors are illustrated as follow:

1) We arrive home at $05.15 \mathrm{pm}$

2) I with my friendship go to in mountain Jae last month

3) I give some food to monkey

4) My brother invite me to walking around that place.

In the sentences "a" and " $d$ ", the students should use past simple verb (regular) because when telling past experiences they should use the second past form of the verb (V2). In the sentences "b" and "c", they should use irregular verb. However, the students use the infinitive without adding the verb with -ed. So, the sentences should have been:

1) We arrived home at $05.15 \mathrm{pm}$

2) Last month, I and my best friend went to the mountain Jae

3) I gave some food to the monkey

4) My brother invited me to walk around that place

b) Auxiliary Verb

According to Ismail (2010), auxiliary verbs are verbs that are used to assist the verb to express the meaning or especially have the grammatical function. It cannot be used without a main verb. Also, auxiliary verb cannot be used with modal verb. Some students in this study made errors in the use of auxiliary verb, they are:

1) I do not know who have that earring

2) I have bad experience

3) I have many friend there

4) I have good experience

As the researcher told before, when we write a recount, normally we used past tense. So the students made errors in this area. In sentence "a" the students use "do not" instead of "did not" because “Do, Don't, Does, Doesn't are used for questions and negatives statement in the present simple tense. However, "Did and Did not" are used in the simple past. Instead the students also should use "Had" because "Had" is past simple verb of "Have", They should have been:

1) I did not know who have that earring

2) I had bad experience

3) I had many friends there

4) I had good experience

\section{c) Modal verb}

Modals are also called auxiliary verbs. They help verbs expressing a wide range of meaning (ability, possibility, necessity, etc). They are not complete verbs, and can only be used with a verb. The usages of modal verb are followed by the simple form of a verb or stay in the base form and they are not followed by an infinitive "to + the simple form of a verb" (except ought, have, and have got). Because of that, the students often make errors in the use of modals. The following modal verbs are used with the present tense: can, ought to, will, shall, may, must. Because in recount we use past time, so the students have to follow the modal verb in the past tense not present tense.

1) We can saw the panorama beautiful in Senggigi beach

2) I will never forget that experience

3) My sister cannot saw the cycle troupe

It should have been:

1) We could see the beautiful panorama in Sengigi beach

2) I would never forget that experience

3) My sister could not see the cycle troupe.

d) Infinitive To

Based on the analysis, some students made errors in producing verb I 
(present verb) or infinitive. They still failed to use the infinitive.

1) We were together ordering bus to went there

2) That time I go to played with my friend

3) My brother invited me to walked around that place

4) Our last semester, my friend and I had planned to went at Sendang Gila to spend our holiday

In the sentences above, the student failed to put the infinitive. They used past simple verb after "to". Besides, the form of infinitive is "to" followed by present verb, It should have been:

1) We rent a bus to go there

2) That time I went to play with my friend

3) My brother invited me to walk around that place

4) Our last semester, my friend and I had planned to go at Sendang Gile to spend our holiday

\section{e) Linking verb}

According to Ellis (2011), when the subject of a sentence is directly linked to its object, the verb used to form that connection is a linking verb. The most common linking verb comes in the forms of the verb to be. The sentence Ali is a good father links Ali, the subject, with the predicate nominative of the sentence, good father. The verb "is" provides the essential link. Verbs like "to see" and "to appear" are other common linking verbs. Though a linking verb may most often come in the form of the aforementioned verb forms, there are a variety of verbs that may be either action verbs or linking verbs, depending upon the context in which they are used. The key difference in determining whether you are dealing with a linking verb or an action verb is whether or not you can substitute a form of to be or sometimes to seem for the verb you are using.

The complements of linking verb (to be) are usually "an adjective" or "a noun". But here the student still made error. We used past tense since the recount function to tell about past experience.
1) It is exhausting journey

2) That is my story in holiday

3) After that we go home and we so tired

4) I am happy go to Kerandangan beach

All of four sentences above were failed to put the "to be" before a noun and an adjective. So, it should have been:

1) It was exhausting journey

2) That was my story in holiday

3) After that we went home and were tired

4) I was happy went to Kerandangan beach

\section{Errors in Subject-verb agreement}

Subjects and verbs must agree with one another in number (singular or plural). Thus, if a subject is singular, its verb must also be singular; if a subject is plural, its verb must also be plural. The students have to remember that in writing a recount they used past tense. In the past tense there is an agreement between subject and verb in this case to be (was,were). If there is no verb in the sentence, we used to be. In contrast, we don't use to be if there is verb in the sentence.

a) When we go to Senggigi beach the panorama is beautiful

b) I am very enthusiastic see the sunshet in Senggigi beach

c) In way we was very tired because Mangsit is so far and many ravine there

d) When I drove the bicycle, I fall and my hand broken

In the sentences above, the students failed to use "was and were". It should have been:

a) When we went to Senggigi beach, the panorama was so beautiful

b) I was very enthusiastic to see the sunset in Senggigi beach

c) In the way we were very tired because Mangsit is so far and many ravine there

d) When I drove the bicycle, I fell off and my hand was broken

3. Errors in article

Basically, an article is an adjective. Like adjectives, articles modify nouns. English has two articles namely: "the" and "a/an". "The" is used to refer to specific or particular nouns. You can use 'the' with any type of noun - plural or singular, 
countable or uncountable; "a/an" is used to modify non-specific or non-particular nouns. Uncountable nouns don't use "a" or "an". For example, advice is an uncountable noun. You can't say "he gave me an advice", but you can say "he gave me some advice", or "he gave me a piece of advice". Kenneth (2011) points out that we call the "the" definite article, "a" the indefinite article beginning with consonant, and "an" the indefinite beginning with vowels $(\mathrm{a}, \mathrm{e}, \mathrm{i}, \mathrm{o}$, $u$ ). In this case, the students' make errors using articles:

a) My cousin and I rent bicycle. Suddenly, when I drive a bicycle I fell and my hand was broken

b) We search an place to break

c) We also happy because beach that we visiting very beautiful

d) Every time, I always sing song with my sister and my father

In sentence (a) the student should used article "a" with the first word "bicycle" and article "the" in the second word "bicycle". In the first time of speaking "a" or "an" is used and in the next time "the" is preferred. In sentence (b) the student should write " $a$ place" not "an place", because the article "an" does with words beginning with vowel sound (a, i, u, e, o). In sentence (c), it should be "the beach" because the student had to repeat the word again, and in the sentence (d) it should be "sing a song". Here song is non-specific because we did not know what song that the students sang. Also the students still use the base verb in the sentences. So, it should have been:

a) My cousin and I rent a bicycle. Suddenly, when I drove the bicycle I fell and my hand was broken

b) We searched a place to break

c) We also happy because the beach that we visited very beautiful.

d) Every time, I always sung a song with my sister and father

4. Errors in pluralization

The plural form of a noun indicates simply that there is more than one of the person or thing in question. For most nouns, the plural form includes the letter "s" at the end of the word. Some nouns only have a plural form, ending with " $s$ " or without (person-people, woman-women, one bus-two buses, one month-two months). The function of pluralization is to show that the noun is more than one. So, the errors in this area are as follows:

a) I was very happy together all my friend

b) Two week ago, I and my friend went to Mangsit beach by bicycle

c) Two year ago, I went to Kerandangan beach with my friends and my teacher

d) I had many new friend there

In four sentences above, the students made erroneous in the plural form of the object. It should have been:

a) I was very happy together all $\boldsymbol{m y}$ friends

b) Two weeks ago, I and my friend went to Mangsit beach by bicycle

c) Two years ago, I went to Kerandangan beach with my friends and my teacher

d) I had many new friends there

5. Errors in conjunction

Bhaskara (2009) points out that a conjunction is the part of speech or word class that serves to connect two words, phrase, clauses, or sentences. There are three types of conjunction. First, coordinating conjunction is used to connect two parts or two words of a sentence that are grammatically equal. The two parts may be single words or clause. Coordinating conjunction usually uses "and, but, or, for, yet, so". The second is Subordinating conjunction. It is used to join a subordinate dependent clause to a main clause. It usually uses "after, before, when, while, as, since, until, as soon as, once, every time, etc". The last is correlative conjunction which is used to connect the elementelement like in the coordinating conjunction but the difference is always used in pair. For example both...and, not only...but also, either...or, neither...nor, In this case, the students still make errors in using conjunction:

a) I walked to see the panorama. It's very amazing

b) I with my friend go to in mountain Jae last month

c) We enjoyed the panorama of Mangsit beach that so beautiful. Not only the panorama but the tourists that sunbathe is beautiful too.

d) On holiday, I with my family spend to my grandmother's house 
In the sentences above, the students failed to put the conjunction. They also still used the present time. The sentences $(a, b$, and d) should be added with "and" (coordinating conjunction), so that the sentence become perfect. Besides, in sentence (c) the students make erroneous in correlative conjunction. It should have been:

a) I walked to see the panorama and it was very amazing

b) Last month, my friend and I went to the Jae mountain

c) We were enjoyed the beautiful panorama of Mangsit beach. Not only the panorama but also the tourists that sunbathe there was beautiful

d) My family and I spent our holiday at my grandmother's house

6. Errors in pronoun

According to Heather (2008), a pronoun can replace a noun or another pronoun. Pronoun consists of several types, including the personal pronoun, the demonstrative pronoun, the interrogative pronoun, the indefinite pronoun, the relative pronoun, the reflexive pronoun and the intensive pronoun.

A personal pronoun refers to a specific person or thing and changes its form to indicate person, number, gender, and case. A nominative personal pronoun indicates that the pronoun is acting as the subject of the sentence. The subjective personal pronouns are "I, you, she, he, it, we, you, they". An objective personal pronoun indicates that the pronoun is acting as an object of a verb compound verb, preposition, or infinitive phrase. The objective personal pronouns are: "me, you, her, him, it, us, you, and them." A possessive pronoun indicates that the pronoun is acting as a marker of possession and defines who owns a particular object or person. The possessive personal pronouns are "mine, yours, hers, his, its, ours, and theirs.

A demonstrative pronoun points to and identifies a noun or a pronoun. "This" and "these" refer to things that are nearby either in space or in time, while "that" and "those" refer to things that are farther away in space or time. The demonstrative pronouns are "this, that, these, and those". "This" and "that" are used to refer to singular nouns or noun phrases and "these" and "those" are used to refer to plural nouns and noun phrases.

An interrogative pronoun is used to ask questions. The interrogative pronouns are "who, whom, which", what and the compounds formed with the suffix "ever" (whoever, whomever, whichever and whatever).

A relative pronoun is used to link one phrase or clause to another phrase or clause. The relative pronouns are "who, whom, that," and "which." The compounds "whoever, whomever, and whichever" are also relative pronouns.

An indefinite pronoun is a pronoun referring to an identifiable but not specified person or thing. The most common indefinite pronouns are all, another, any, anybody, anyone, anything, each, everybody, everyone, everything, few, many, nobody, none, one, several, some, somebody, and someone.

A reflexive pronoun is referring back to the subject of the clause or sentence. The reflexive pronouns are myself, yourself, herself, himself, itself, ourselves, yourselves, and themselves. An intensive pronoun is a pronoun used to emphasize its antecedent. Intensive pronouns are identical in form to reflexive pronouns, based on my analysis, the students make errors in this area. They are:

a) After wards bring me to the hospital by brother

b) I help my uncle to decorate room anniversary and decorate bedroom

c) After that, we eat together and we take bath in waterfall of Benang Stukel

d) One day, my visiting Senggigi beach with my friend

e) We enjoyed the panorama of Mangsit beach who so beautiful

f) The story that never forgot

In the sentences "a" and "b" the students failed to recognize the possessive pronoun. In the sentences " $\mathrm{c}, \mathrm{d}$, and $\mathrm{f}$ "the students failed to use personal pronoun (nominative pronoun). And in the sentence " $\mathrm{e}$ " the students failed to recognize the relative pronoun, So, it should have been:

a) Afterwards, my brother took me to the hospital

b) I help my uncle to decorate his anniversary room and bedroom 
c) After that, we ate together and took bath in waterfall of Benang Stukel

d) One day, I visited to Senggigi beach with my friend

e) We enjoyed the panorama of Mangsit beach which so beautiful

f) The story that I never forgot

7. Error in preposition

According to Faisal (2011), a preposition is a word showing a relationship between nouns or pronouns and some other word in the sentence. It can show the relations of direction, time, location, or even exclusion. Word used before noun: a member of a set of words used in close connection with, and usually before, nouns and pronouns to show their relation to another part of a clause. In using preposition, the students still make errors. They failed to put the preposition based on the context.

a) With there that experience, we can to feel together with my friendship

b) The place, I meant Sendang Gia is so crowded and full with people

c) We decided to went to the Sendang Gila

d) When evening, we were to go home

Based on the sentences above, in the sentence "a", the students should use "because of". It is a phrasal preposition. As I stated above that the preposition should always be followed by a noun only. In sentence " $b$ " the student failed to put the pair preposition of "full". Beside, in sentence "c" the student put two prepositions. And In sentence "d and e" they failed to recognize time expression, It should have been:

a) Because of that experience, we can feel the togetherness

b) The place, I meant Sendang Gila was so crowded and full of people

c) We decided went to the Sendang Gila

d) In the evening, we went home

After classifying and explaining all errors made by the students into seven kinds of grammatical errors, the researcher calculated the frequency of every type of errors as follow:

\section{Errors in verb groups}

The errors on this area are 97 errors, the total errors are 187. So, the frequency of these errors is:

$$
\begin{aligned}
\mathrm{P} & =\frac{n 1}{\Sigma N} \times 100 \% \\
& =\frac{97 \times}{187} \times 100 \% \\
& =51.6 \%
\end{aligned}
$$

2. Errors in subject-verb agreement

The total errors in this area are 21 errors. So, its frequency is:

$$
\begin{aligned}
\mathrm{P} & =\frac{n 1}{\sum N} \times 100 \% \\
& =\frac{21 \times 100 \%}{187} \\
& =11.2 \%
\end{aligned}
$$

3. Errors in article

The occurrences of this area are 16 errors. So, its frequency is:

$$
\begin{aligned}
\mathrm{P} & =\frac{n 1}{\Sigma N} \times 100 \% \\
& =\frac{16}{187} \times 100 \% \\
& =8.5 \%
\end{aligned}
$$

4. Errors in preposition

The errors in preposition are 30 errors. So, its frequency is:

$$
\begin{aligned}
\mathrm{P} & =\frac{n 1}{\Sigma N} \times 100 \% \\
& =\frac{30}{187} \times 100 \% \\
& =16.0 \%
\end{aligned}
$$

5. Errors in pluralization

The total of these errors is 6 errors. So, its frequency is:

$$
\begin{aligned}
\mathrm{P} & =\frac{n 1}{\Sigma N} \times 100 \% \\
& =\frac{6 \times 100 \%}{187} \\
& =3.2
\end{aligned}
$$

6. Errors in pronoun

The occurrences of this error are 11 errors. So, its frequency is:

$$
\begin{aligned}
\mathrm{P} & =\frac{n 1}{\Sigma N} \times 100 \% \\
& =\frac{11}{187} \times 100 \% \\
& =5.9 \%
\end{aligned}
$$

7. Errors in conjunction

The total of the last error is 7 errors. So, its frequency is:

$$
\mathrm{P}=n 1 \times 100 \%
$$




$$
\begin{aligned}
& \overline{\Sigma N} \\
= & \frac{7 \quad \times}{187} 100 \% \\
= & 3.7 \%
\end{aligned}
$$

The result of the analysis can be tabulated as follows:

Table 1. the frequency of students' errors

\begin{tabular}{clcc}
\hline No. & Type of Error & $\begin{array}{c}\text { Number } \\
\text { of Error }\end{array}$ & Percentage \\
\hline 1 & $\begin{array}{l}\text { Error in verb } \\
\text { groups }\end{array}$ & 97 & $51.9 \%$ \\
\hline 2 & $\begin{array}{l}\text { Errors in subject- } \\
\text { verb agreement }\end{array}$ & 21 & $11.2 \%$ \\
\hline 3 & Errors in article & 16 & $8.5 \%$ \\
\hline 4 & $\begin{array}{l}\text { Errors in } \\
\text { preposition }\end{array}$ & 30 & $16.0 \%$ \\
\hline 5 & $\begin{array}{l}\text { Error in } \\
\text { pluralization }\end{array}$ & 6 & $3.2 \%$ \\
\hline 6 & $\begin{array}{l}\text { Errors in } \\
\text { pronoun }\end{array}$ & 11 & $5.9 \%$ \\
\hline 7 & $\begin{array}{l}\text { Errors in } \\
\text { conjunction }\end{array}$ & 7 & $3.7 \%$ \\
\hline
\end{tabular}

Based on the result in the table above, the students still made quite high frequency of grammatical errors. The researcher found the most errors on students writing recount. It is easily seen that errors in verb groups $97(51,9 \%)$ are the most serious errors that the students $\mathrm{X}$ MIA SMA Tri Dharma Kosgoro made. It means that they have not mastered the use of verb groups especially the use of past verb. Based on the analysis, a few students had little understanding in using past tense. Besides, some students did not know when to use present verb (to be) and did not know the form of past verb. Instead, in writing recount text they used past forms. The students believed that past tense as their difficult in writing recount.

The students' errors in verb groups' rates take the highest position than the six other errors. Based on the analyses of their writing, the second high errors in student's writing was errors in preposition $30(16.0 \%)$, it was because the students' were still confused when using the preposition "on", "in", or "at". Third, errors in subject-verb agreement 21(11.2\%), there is no rule in agreement between subject and verb in Bahasa Indonesia. Because of that, the students make errors in this area. Fourth, errors in article
$16(8.5 \%)$, in this case the students still felt difficult in differentiating the use of indefinite and definite article. Fifth, errors in pronoun $11(5.9 \%)$. The students still confused in determining which pronoun should be used. The last was errors in conjunction $7(3.7 \%)$ and errors in pluralization $6(3.2 \%)$. Both of them were the least errors students made, it means that the students understood the use of conjunction and pluralization.

\section{Possible Reasons for Students' Errors}

Based on the analysis of the student's questionnaire, the researcher would describe some causes of the students' errors in writing recount text; they were mistranslation, first language interference, overgeneralization, ignorance of rules restriction, and other causes on lack of grammatical knowledge and vocabulary knowledge.

1. Mistranslation

The students still felt difficult when translating their writing from Indonesian to English because they generally translate their first language sentence to the target language word by word. It occurs because the students found it difficult to develop their ideas as a result of lack of practice. For example:

a) One month ago, I and friend I go to school friend together

b) I and friend to go home from school

c) Because beach which visiting very beautiful with water which clear and blue

d) We feel satisfied with panorama that beautiful

The sentences should have been:

a. One month ago, my friend and I went to school together

b. After school, my friend and I immediately went home

c. Because the beach that we visited is so beautiful with the blue color

d. We felt satisfied with the beautiful panorama

\section{First language interference}

In this case, the errors occurred because as a result of the use of element from one language to the second language (L2), or it was because of the student's mother tongue on his production of the target language. In Indonesian the past verbs are the same as the present verbs. For example: 
a. We go see panorama in the senggigi beach yesterday

b. I with my friendship go in mountain Jae last month

It should have been:

a. Yesterday, we went to see the panorama in Senggigi beach

b. Last month, my friend and I went to the Jae mountain

3. Overgeneralization

According to Richard (1971), overgeneralization occurs when the learners create a deviant structure on the basis of their experience of other structure in the target language. For example:

a. I was went to Gili Terawangan

b. My friend and I sings song together

c. I and my big family gone to Gili Terawangan

The sentences should have been:

a. I went to Gili Terawangan

b. My friend and I sing a song together

c. My big family and I went to Gili Terawangan

4. Ignorance of rules Restriction

It involved the application of rules to contexts. In this case, the students applied wrong rules to a certain expression or sentences. The errors occurred because the students did not master the structure of the target language. Moreover, as researcher mentioned earlier in this thesis that in writing recount the simple past is used. For example:

a. I am very shocked with surprise that my darling do

b. We decide to went there because it has a nice view especially the waterfall

c. When we go to Senggigi beach panorama was beautiful

It should have been:

a. I was very shocked with the surprise that my darling did

b. We decided to go there because it has a nice view especially the waterfall

c. When we went to Senggigi beach, the panorama is beautiful

5. Lack of Grammatical Knowledge and Vocabulary

Both of them were the other underlining reasons for students' errors. The student's lack of grammatical knowledge made them less competent to make good sentences. In terms of vocabulary, having less vocabulary knowledge avoided the students to create good sentences in writing recount text. Therefore, they have to master a lot of vocabulary. The knowledge of grammatical and vocabulary are important to construct good recount or writing.

\section{CONCLUSSION}

The implementation of grammar error analysis has improved the students' skill in recount text. This has been showed by the improvement of students' percentage score in pre-test and post-test, from 45.7 to $51.7 \%$. This paper has also identified some errors made by the students. In this case, the type of error analysis of grammar could also help them to understand the type of error they had made in the treatment (implementing process). The kinds of the students' grammatical errors could be classified into seven categories namely errors in verb groups, errors in subject and verb agreement, errors in article, errors in pluralization, errors in conjunction, errors in preposition, and errors in pronoun. Based on the questionnaire distributed to the students, the possible factors that may cause the errors were mistranslation, first language interference, overgeneralization, ignorance of rules restriction, lack of grammatical knowledge and vocabulary.

\section{REFERENCES}

Arikunto, S. (2006). Prosedur Penelitian. Jakarta: PT Rineka Cipta.

Azar, B.T. (1993). Fundamentals of English Grammar. Jakarta: Binarupa Aksara

Bhaskara, S.(2009). Part of Speech Pronoun. Taken from http://swarabhaskara.com/parts-ofspeech/pronoun/.

Hartanti, P. (2007). Analysis of Grammatical Error in Writing. Taken from http://cupep.blogspot.com/2010/01/skripsianalysis-of-grammatical-error.html.

Haryanto, (2007). Grammatical Error Analysis in Students' Recount Texts. The Case of the Twelfth Year Students of SMA N 1 Slawi in the Academic Year of 2006/2007. A published thesis of English Department Faculty of Language and Arts Semarang State University. 
Hasyim, S.(2001). Error Analysis in the Teaching of English. Taken from http://puslit.petra.ac.id/journals/letters/.

Hayatunnufus. (2006). A Study on the Students' Ability in Writing a Simple Recount Text. A Survey at the Second Year Students of SMP 11 Mataram in Academic year 2005/2006. An unpublished thesis of S1 PBS FKIP Unram. Mataram: UNRAM.

Hedda. (2009). Definition of writing. Taken from http://www.heddatan.com/a-definition-ofwriting.html

Hernayana. (2009). Error Analysis in Using Simple Past Tense Committed by Second Year Students of MTs Qamarul Huda Bagu Pringgarata in Academic Year 2009/2010. An Unpublished Thesis of Sarjana Degree in English Education, FKIP Unram, Mataram: UNRAM

Hopkins, David. 1993. A Teacher Guide to Classroom Research. Great Britain: Edmundsburry Press Ltd

Istiqomah, A. (2009). Common Grammatical Errors in Writing Recount Text at the First Year Students of Senior High School at SMAN 3 Tegal in Academic Year 2009/2010. A published Thesis of Teacher Training and Education Faculty of Pancasakti University Tegal.

Koentjaraningrat. (1997). Metode-Metode Penelitian Masyarakat: Edisi Ketiga. Jakarta: PT Gramedia Pustaka Utama

Midi, I. (2010). Auxiliary Verb. Taken from http://ismailmidi.com/berita-130-sauxiliaryverbs.html.
Murphy, R. (1994). English Grammar in Use. Cambridge: Cambridge University Press.

Nasution, S (2009). Metode Research: Penelitian Ilmiah. Jakarta: Bumi Aksara

Purwati, D. (2020). Factors Supporting and Hindering the Learning of English as an Additional Language Experienced by a Female IndonesianStudent. JurnalSainsSosioHumanio $r a, 4(1), 94-101$.

Sakkir, G. (2020). The Effectiveness of Pictures In Enhance Writing Skill of Senior High School Students. Interference: Journal of Language, Literature, and Linguistics, 1(1).

Seaton, A.(2007). The Recount Genre. Taken from http://www.andrewseaton.

com.au/grecount.htm. Straus. J. (2010). Subject Verb Agreement. Taken from www.grammarbook.com/ grammar/subjectverbagree. asp.

Volker, H. (2006). Grammar, Writing, and Technology: A Sample Technology-supported Approach to Teaching Grammar and Improving Writing for ESL Learners. Taken from https://calico.org/html/article_116.pdf.

William, M. K. (2006). Nonprobability Sampling.Taken from http://www.william.com.au/non-probabilitysample.htm.

YIN, R, K. (2009). Studi Kasus: Desain Metode. Jakarta: PT Raja Grafindo Persada 